University of Nebraska - Lincoln

DigitalCommons@University of Nebraska - Lincoln

Journal for the Advancement of Developing Institute for the Advancement of Developing Economies

Economies

2020

Homeownership Rate and Other House Price Determinants

Impacts on New House Prices in Colombia

Hector A. Botello-Peñaloza

Follow this and additional works at: https://digitalcommons.unl.edu/jade

Part of the Econometrics Commons, Growth and Development Commons, International Economics Commons, Political Economy Commons, Public Economics Commons, and the Regional Economics

Commons

This Article is brought to you for free and open access by the Institute for the Advancement of Developing Economies at DigitalCommons@University of Nebraska - Lincoln. It has been accepted for inclusion in Journal for the Advancement of Developing Economies by an authorized administrator of DigitalCommons@University of Nebraska - Lincoln. 


\title{
Homeownership Rate and Other House Price Determinants Impacts on New House Prices in Colombia
}

\author{
Hector A. Botello-Peñaloza* \\ Department of Economics, Industrial University of Santander, Colombia
}

\begin{abstract}
Homeownership remains a preferred form of tenancy in different parts of the world. The attractions of security, stability, investment potential and a sense of pride outweigh the fear of price instability. For this reason, the Colombian government has encouraged in recent years, various demand policies that have sought to promote the increase in the number of homeowners. However, these ideas could have a severe impact on prices in the real estate market. Therefore, this study seeks to examine the effect of homeownership rate on new house prices in an emerging country with low real estate ownership, credit restrictions and average per capita income. The study uses panel data model to examine the influence of housing tenancy and other variables on the variation of housing prices in Colombia. Data were obtained from various sources including the Central Bank of Colombia, Financial Superintendence of Colombia, and National Administrative Department of Statistics of Colombia. The results show that homeownership rates have a positive effect on the price of new homes, which supports the hypothesis of the research. The population growth of the cities is the factor that is most relevant when explaining the price variations.
\end{abstract}

Keywords: Housing market, housing price index, low income, tenancy, South America. *Corresponding author: hectoralbertobotello@gmail.com

JEL Classification: C33, D12, D91, J61, R21

\section{INTRODUCTION}

Housing is an important part of household assets. According to the Federal Reserve, about onethird of the gross assets of U.S. households come from the value of their home (Badev et al., 2014). The choice of this asset as a relevant asset within personal finances is due to its stability, performance, and security. Therefore, there has been a growth in the demand along with the government policies that promote ownership. In the period 1940-2000, mortgage credit doubled, reaching an average of $40 \%$ of GDP in developed countries (Badev et al., 2014). These policies have been reflected in the increase in the rate of home ownership. In the United States, it rose from about $45 \%$ to $64.5 \%$ of the GDP between 1940 and 2016; and in Britain from $30 \%$ to $63.5 \%$ in the same period. Consequently, real estate is one of the most important assets in the market. According to the consulting firm Savills PLC, all properties in the world, including commercial and residential, are estimated to be worth 228 trillion dollars (Betancur et al 2018). This is equivalent to 12 times the GDP of the US or 18 times the GDP of China. In comparison, the value of all the gold that has been mined throughout history is $\$ 7.5$ trillion (Ahearne et al., 2005; Betancur et al 2018). 
With this in mind, the Colombian government has had a series of programs to encourage the acquisition of housing. These programs have led to the high growth of the main cities, expanding irregularly and leaving other areas depopulated. To transform this trend, governments have promoted the densification of already urbanized areas that have the necessary infrastructure. In the first instance, it encouraged supply-side subsidies; however, in recent years, the government has focused on programs to promote demand (Escallón, 2011). The "Mi casa ya" program is the most recent version of this approach. This public policy provides subsidies to families for the purchase of new homes. The subsidy pays $20 \%$ of the down payment on the house. In addition, the household receives $4 \%$ interest rate on the mortgage loan each month (Acuña, 2018). It manifested in a lower monthly payment of the mortgage loan by the beneficiary to the granting entity.

However, these programs can bring distortions to the housing market. The economic literature agrees that the balance of supply and demand guides the price of housing in the short term. Therefore, programs that seek to increase the demand for this good in an excessive manner will bring volatility to the markets and possible inefficiencies to the economy (Ortalo-Magne \& Rady, 1999). This is especially true in the more densely populated urban centers where inelasticity in the supply of real estate is greater due to demographic pressures, lack of space and transport congestion. These factors have increased housing price volatility with political, economic, and social consequences (Kuethe \& Pede, 2011). According to Furman (2015) and Paciorek (2013), the hardening of land regulations, limiting private construction, has produced the lack of new residential units. In the 1970s, governments in developed countries built 10 houses per thousand inhabitants, while in the last twenty years; the average has been 4 per thousand inhabitants (Kok et al., 2014).

Increased volatility in house prices has caused frequent periods of economic bubbles and recessions. According to The Economist, in the second half of the 20th century, a quarter of the recessions in the rich world were associated with declining house prices (Huang \& Tang, 2012). These crises were more severe and lasted longer than others last. However, the damage caused by poorly managed housing markets is much deeper than financial crises and recessions (Huang \& Tang, 2012).

This phenomenon may be due to the rigidity of resource mobility caused by home ownership. If households have a relatively high marginal propensity to invest in their housing, they will have less liquidity for other purposes (Klyuev \& Mills, 2007). On the other hand, authors such as He et al. (2015) suggest that, instead of removing liquidity, houses can be used as collateral to obtain more credit. Although this perspective can only be obtained in countries with developed financial instruments and institutions that promote low transaction costs.

On the immobility of factors and the housing market, Oswald (1996) established a conjecture on the permanence of the high unemployment rates that explain the moment when families stop living in rent and start living in property. This prevents labor flexibilization and geographic mobility in search of new job opportunities. Therefore, it can negatively affect the unemployment rate in cities.

Home ownership has been identified as a source of intergenerational inequality. While generations born after the Second World War have on average larger houses. Young people must rent increasingly cramped and expensive places like in Hong Kong (Chan, 2019; Lai \& Wang, 1999; 
Lens \& Monkkonen, 2016). The policy implications of housing inequalities are more complex than has been studied so far. Adler \& Ansell (2020) found that the British living in areas where house prices are stagnant were more likely to vote for Brexit in 2016, and the French for the far-right National Front in the 2017 presidential elections.

In this sense, this paper seeks to estimate the effects of homeownership rate on housing price changes in Colombia. From the methodological point of view, the annual data series from 2002 to 2019 for the three main Colombian cities was collected with available information on the price of new housing. Other price determinants are included to detect associations between variables and report their significance through a panel data model. The main hypothesis of this work is that the higher rate of homeownership reduces housing availability in the study territories and therefore the price of housing increases. In developing countries this relationship will be greater given the strong presence of irregular settlement and greater regulation of housing. Thus, the main objectives of this study are to (1) examine the impact of homeownership on price of housing and (2) further evaluate other possible determinants of housing prices in Colombia using data from three key cities.

To achieve the objectives of the research, the document is organized in five sections, following this introductory section. The next (second) section is a review of the literature on the determinants of housing prices and how the tenancy rate can influence housing behavior. In the third part, the methodological design is presented, starting with the sources of information and the model implemented. The fourth section shows the results of the characterization of the tenancy rate in Colombia and the results of the model. Finally, the conclusions of the research are presented.

\section{LITERATURE REVIEW}

Several authors agree that the balance between housing supply and demand is the key long-term determinant of housing prices (Stephens, 2011; Tsatsaronis \& Zhu, 2004). Peña et al. (2004) make a compilation of these factors and state that among the factors involved in the evaluation of housing prices are those on the demand and supply side (Table 1). On the housing price determinants in Spain, in order of relevance are the consumer price index (CPI), construction costs, gross domestic product (GDP) per capita, the price of rents, the volume of available credit, the reference interest rate of the mortgage market, completed free housing and the population between 25 and 34 years of age (Rodriguez et al., 2018).

\section{Table 1: The Determinants of Housing Prices from the Demand and Supply Sides}

\begin{tabular}{|l|l|}
\hline Demand-side determinants & Supply-side determinants \\
\hline $\begin{array}{l}\text { - Demographics: population size, age group, population density, } \\
\text { marriage, and divorce rates }\end{array}$ & - Availability of credit \\
\hline - Economic: income level & $\begin{array}{l}\text { - Number of existing } \\
\text { dwellings }\end{array}$ \\
\hline - Financial: interest rates, volume of available credit & - Construction costs \\
\hline - Fiscal: tax discounts for mortgage loans and housing investment & \\
\hline
\end{tabular}

Source: Peña et al. (2004) 
Several authors have identified the expansion of the real estate supply as fundamental to explaining the growth of housing prices. But Favara and Imbs (2015) and Catte et al. (2004) find that house prices appear to be subject to greater swings in countries where the supply of housing is relatively inelastic (for example, because of restrictive zoning regulations) and where favorable fiscal policy on mortgage loans increases interest and debt on real estate.

The literature has also shown that certain movements in the economic cycle of certain countries have been caused by the indebtedness promoted by the increase in the price of housing (Illing et al., 2018). According to the International Monetary Fund (IMF), increasing household debt drives economic growth and employment (Lai et al., 2017). Nevertheless, households must slow down spending to pay back their loans, so these effects are reversed. Future growth becomes slower than it would otherwise have been (Igan \& Kang, 2011). At the level of large cities, where productivity and wages are much higher, this reduces overall GDP (Clayton, 1996).

Based on the above, it can be inferred that to a certain extent the increased homeownership limits the supply of housing and increases the rigidity of this market by influencing prices upwards. The microeconomic static analysis mentions that the relationship between demanded quantities and prices is one way. However, defining this relationship is not simple. According to Shiller (2007), within the economic literature it is recognized that excessive increases in housing prices are relatively unusual processes given that the purchase of a house is both an investment and a consumption decision. For Hashim (2010), the sustainability of housing prices is mostly explained by the demand factor. The supply side is complementary, where the regulation of territories will guide affordability. With the level of income above the poverty line, the cost of low credit and the leverage offered by financial institutions, households could own and make their monthly mortgage payment without suffering. In addition, the decision to buy rather than rent is a decision not only to consume different types of housing services but also to lead a different kind of life. According to Shiller (2007) paying too much attention to housing as an investment can encourage speculative thinking and therefore excessive housing market volatility.

Since the late 1990s, the United States has experienced a boom in house prices that was correlated to a substantial increase in the rate of home ownership. Between 1960 and 1990, the rate of home ownership was relatively constant. The psychology of price growth motivated potential homeowners and moved other industry players, for example, those destined to finance and calculate the risk of these investments (Shiller, 2007). The data show that subprime mortgages accounted for one-fifth of all mortgages in 2005 compared to 1990 when they were virtually nonexistent. This indicates that the new loans were concentrated on lower-income individuals and racial minorities (Shiller, 2007).

The effects of price on property can be two-way; increased demand for a good can lead to price increases and vice versa. Similarly, the economic literature has found that governments have been inclined to promote home ownership through various policies in much of the world. Shiller (2007) also reviews that a significant part of the behavior of the variability of home ownership rates is not well explained by any economic or demographic variable. According to Fisher and Jaffe (2002) they could explain only $50 \%$ of the variability in homeownership rates between countries. Using a fixed-effect panel data model for different countries, they found that the home ownership rate is negatively correlated with per capita GDP. Consumer choice on housing demand can also be 
determined by their substitutes. In the case of the purchase of housing, it is its rent. This is the choice of people who are currently unable to take on the responsibilities of managing the household, who are likely to move soon or who have other plans for their time (Hashim, 2010).

Herkenhoff, Ohanian, and Prescott (2018) analyze how policies restricting land use have affected resource reallocation, relative prices, aggregate output and productivity, and the share of regional employment. One of these effects is the immobility of the labor factor by increasing market rigidities that negatively affect its dynamics. Its results suggest that easing land use restrictions can contribute significantly to higher aggregate economic performance. This conclusion joins Glaeser and Gyourko (2003) and Furman (2015) in arguing that land and housing regulations slow economic growth. Both documents synthesize existing work that provides a set of facts related to economic performance and regulation. They also argue that large differences in house prices and different expectations of house price inflation between regions create a mobility trap, making it difficult for some people to move from one region to another and deterring others from doing so altogether.

Fiscal orientation can also affect urbanization policies and consequently price movements. For example, when local governments can take advantage of the benefits of housing taxes, positive environments are created for real estate development. This would create a more elastic supply of housing and thus reduce speculation on housing prices. According to Bourassa and Hoesli (2010) this situation has allowed housing prices in Switzerland to fluctuate less than in other Organization for Economic Cooperation and Development (OECD) countries. In other countries, the elasticity of housing supply has been restricted while demand has increased by creating incentives for households to spend more money on the housing market such as systematic reduction of interest rates, as well as regulatory measures to limit housing bubbles (Wu \& Li, 2018; Saks, 2004; Glaeser, Gyourko \& Saks, 2005). However, according to Sierra and Tarazona (2011), housing provision does not automatically solve the conditions of poverty of households; in fact, it may deepen it in some contexts. From an individual perspective, Fischel (2009) hypothesizes that homeowners have an incentive to resist additional real estate development in their neighborhoods, as by doing so they help preserve the value of their property. Therefore, as homeownership increases, housing construction could be expected to decrease.

In the model proposed by Banks, Blundell, and Oldfield (2004) it is estimated that people living in places with higher house price risk should own their first home at a younger age, should live in larger houses and should be less likely to refinance. However, some research shows an increase in the rental rate among younger populations. This shows that these generations have assumed fewer obligations due to the absence of adequate financial products to insure this risk, which will lead people to invest in housing early in the life cycle as a way to insure future price fluctuations.

However, the decision to purchase housing is not only driven by countries' income. Sierra and Tarazona (2011) comment that in the context of developing countries there is even evidence that many tenants are better off than some owners because of the weight of the informal housing market. For this reason, access to property should not be the only alternative to be considered in policies for the provision of social housing. Huang and Tang (2012) affirm that Romania, a lowermiddle-income country, has a $92 \%$ of home ownership, while Switzerland and Hong Kong, highincome countries, have less than $50 \%$. Therefore, it can be inferred that urbanization policies are 
one of the most important determinants of household tenancy by allowing access to quality housing not necessarily with ownership.

According to Blanco and Volpe (2015), Colombia is the country with the highest housing rental rate in Latin America. In 2018, there were 13.5 million occupied homes in Colombia. Of these, $40 \%$ of households in Colombia were homeowners, while $57 \%$ were renters. There were also $3 \%$ in other forms of informal tenancy such as de facto occupation and without title. According to the study by Cibils et al. (2014), 37\% of the homes that people acquire have a deficit, both quantitatively and qualitatively. That is, they may lack title to property, basic water services, electricity, transportation, adequate infrastructure, and are in settlements or in high-risk areas.

In summary, the literature review shows two ideas. Firstly, it shows how price cycles can be related to homeownership rates. Similarly, government regulation can affect housing markets. The lack of liquidity caused by the indebtedness or rigidity of its main asset can increase mortgage arrears and replacement rates, in addition to affecting housing construction and intergenerational wealth (Benjamin et al., 2004). Secondly, the international literature has focused on developed countries where housing policies are structured and institutionalized while housing formality allows for continuous monitoring. Accordingly, the main contribution of this document to the literature is to the study of housing price determinants by considering the tenancy rate variable under a structured real estate market environment in an emerging country with large housing deficits and low-income population. The study also contributes to the regional analysis of new housing price dynamics in Colombia, supported by municipal-level data and panel data models.

\section{METHODOLOGY}

\subsection{Model}

To study the relationship between home ownership and home price volatility, it is necessary to configure a model that can monitor the relationship in different geographical entities. Since Colombia is an extremely diverse country, geographically and economically, it is expected that its real estate market will also show such characteristics. In this sense, the present investigation uses a panel data model that measures the influence of housing ownership on the average volatility of housing prices. This methodology is used to counteract the multiple identification problems that can arise from simultaneity, spatial interaction, and unobserved spatial self-correlation between variables. In general, these models include individuals (i.e., cities) within a series of periods in time; that is, they combine two dimensions: the temporal and the structural. In this work, the temporal elements would be the years from 2004 to 2019 and the structural one, the main cities of the country.

The main advantage of applying and studying the panel data as opposed to a multivariate linear regression model is to be able to capture the unobservable heterogeneity of the phenomenon to be studied, either among individuals or over the time investigated. According to Burdisso (1997), individual effects affect each individual specifically and are invariable over time. On the other hand, the temporal effects are those that affect all the cases of study in a uniform way but that are variable in time. This type can be related to, for example, macroeconomic shocks or the introduction of policies that can affect all agents equally. 
With these assumptions, it is possible to reach this equation:

$$
Y_{i t}=\alpha_{i t}+X_{i t} \beta+u_{i t}
$$

Where $\mathrm{Y}$ is the dependent variable. In this research, $\mathrm{Y}$ is the variation in new home prices. On the other hand, $\mathrm{X}$ is a vector of independent variables. Finally, $\mathrm{u}$ is the non-deterministic error of the model. The observation unit (i) is one of the three main cities of Colombia: Medellin, Cali, and Bogotá. The logarithm of the standardized New Housing Price Index (NHPI) is considered the dependent variable $(\mathrm{Y})$ in each year $(\mathrm{t})$. In the case of the vector of independent control variables (X), determinants of housing prices named in Table 1 are used. The equation to be estimate will be:

$Y=a_{o}+\beta_{1} X_{i}+\beta_{2} Z_{i}+\beta_{3} W_{i}+\beta_{4} D_{i}+\beta_{5} E_{i}+B_{6} H_{i}+\beta_{7} G_{i}+\beta_{8} P_{i}+\vartheta_{i} t_{i}+U_{i t}$

Where Y corresponds to the log of the New Housing Price Index. a_o is a constant. The other variables include log of the population growth $(\mathrm{X}), \log$ of the population density $(\mathrm{Z}), \log$ of the income per capita (W), log of the value of mortgages (D), log of the variation in the area of housing construction (E), log of the public spending $(\mathrm{G}), \log$ of the population $(\mathrm{P})$, while the variable of focus is the percentage of people who own their homes $(\mathrm{H}) . t_{i}$ is the period of time analyzed. The error of the model is represented by $U_{i t}$. These variables are introduced in their lagging to make effective their temporary impact on the evolution of the housing price.

$\beta$ and $\vartheta_{i}$ are coefficients. The coefficients in the linear models are interpreted as the percentage increase or decrease of the dependent variable exercised by the presence of each of the characteristics of the cities. For the categorical ones, the coefficient measures the relative variation as a comparison of a base characteristic.

The reading of the panel data models is done through the hypotheses in the behavior in its error components $\left(U_{i t}\right)$. The error term included in equation (1) can be broken down as follows:

$$
U_{i t}=\mu_{i}+\delta_{t}+\varepsilon_{i t}
$$

Where $\mu_{\mathrm{i}}$ represents specific unobservable effects that vary between individuals but not over time. While $\delta_{\mathrm{t}}$ corresponds to temporal effects and $\varepsilon_{i t}$ the random error. It is possible to establish different cases of the model, according to the hypotheses that are woven around. If its value is zero, there is non-unobservable heterogeneity among the cities. The error $U_{\text {it }}$ is the error within a general linear regression model, fulfilling all the assumptions of the model. The second alternative is to assume non-zero and is fixed for all cities, i.e., non-observable heterogeneity will be incorporated into the model constant. The third way is to treat $\mu_{i}$ as a random unobservable variable that varies between individuals, but not over time; in this case we will have that each company has differentiating characteristics in relation to the others. With each alternative, the panel data model receives a name (fixed, random, dynamic effects, etc.).

Isolating this effect, the interest of this research is to verify the hypothesis of $\delta_{\mathrm{t}}$ being positive, different to zero and significant, given that it would indicate that the housing ownership has effects 
on the price of housing by means of the restriction of the use of resources and the inelasticity of the housing offer.

\subsection{Data}

Data on housing prices was obtained from the Central Bank of Colombia through the New Housing Price Index (IPVNBR). This measures the monthly evolution of new housing prices in the three main cities of Colombia: Bogotá, Medellín, Cali and the surrounding municipalities of Bogotá (Chía, Cota, Cajicá, Tabio, Tenjo, La Calera, Sopó, Guaymaral, Funza, Madrid, Mosquera, Facatativá, Soacha and Ciudad Verde). This in a superlative Fisher price index with a fixed base (December 2006), for which the prices and areas of all new properties available for sale in the reference month are used. The series runs from 2004 to 2019. On the other hand, data on loans for house purchase are was provided by the Superintendence of Finance of Colombia. Data on home ownership was calculated annually based on the Integrated Household Survey. It was calculated as the percentage of people who own their homes or are paying for them. The socioeconomic characteristics with which the characterization of tenancy is carried out are also taken from this survey. The variables of economic activity, unemployment, demographics, prices of other goods and government income were obtained from the National Administrative Department of Statistics (DANE). Table 1 summarizes the variables used in the study. This is a 16-year dataset for three cities (Medellin, Cali and Bogota).

Table 2: Summary of Variables Used in Evaluating the Determinants of New House Prices in Colombia by City (2004 to 2019)

\begin{tabular}{|l|c|c|c|c|}
\hline City: Cali & & & & \\
\hline Variable & Mean & Std. Dev. & Min & Max \\
\hline $\begin{array}{l}\text { New housing construction area (square } \\
\text { meters) }\end{array}$ & 819,822 & 331,777 & 262,520 & $1,490,637$ \\
\hline Annual total mortgage (billion pesos) & 2,030 & 1,540 & 906 & 5,380 \\
\hline Annual public spending (billion pesos) & $1,347.506$ & 467.870 & 551.169 & $2,168.613$ \\
\hline Monthly household income (pesos) & $1,305,388$ & 448,275 & 652,780 & $2,190,550$ \\
\hline Housing Price Index (2006=100) & 135 & 34 & 87 & 196 \\
\hline Population (persons) & $2,343,382$ & 120,516 & $2,146,598$ & $2,525,219$ \\
\hline $\begin{array}{l}\text { Homeownership rate (\% of the population }>18 \\
\text { years of age) }\end{array}$ & 50.2 & 3.8 & 39 & 56 \\
\hline Population density (persons per km ${ }^{2}$ ) & 6,135 & 315 & 5,619 & 6,611 \\
\hline Population growth (percent) & 1.10 & 0.10 & 0.90 & 1.40 \\
\hline City: Bogota & & & & \\
\hline Variable & Mean & Std. Dev. & Min & Max \\
\hline $\begin{array}{l}\text { New housing construction area (square } \\
\text { meters) }\end{array}$ & $3,546,159$ & 893,861 & $1,860,889$ & $5,244,508$ \\
\hline Annual total mortgage (billion pesos) & 8,450 & 6,230 & 3,200 & 21,900 \\
\hline Annual public spending (billion pesos) & $1,177.797$ & 356.271 & 636.248 & $1,986.641$ \\
\hline Monthly household income (pesos) & $1,196,678$ & 376,123 & 609,079 & $1,881,341$ \\
\hline
\end{tabular}




\begin{tabular}{|l|c|c|c|c|} 
Housing Price Index (2006=100) & 150 & 44 & 84 & 218 \\
\hline Population (persons) & $7,499,234$ & 491,612 & $6,718,492$ & $8,269,045$ \\
\hline $\begin{array}{l}\text { Homeownership rate (\% of the population }>18 \\
\text { years of age) }\end{array}$ & 42.40 & 3.80 & 36 & 48 \\
\hline Population density (persons per km ${ }^{2}$ ) & 4,225 & 277 & 3,785 & 4,659 \\
\hline Population growth (percent) & 1.40 & 0.10 & 1.30 & 1.60 \\
\hline City: Medellin & & & & \\
\hline Variable & Mean & Std. Dev. & Min & Max \\
\hline $\begin{array}{l}\text { New housing construction area (square } \\
\text { meters) }\end{array}$ & 957,810 & 232,836 & 594,075 & $1,455,232$ \\
\hline Annual total mortgage (billion pesos) & 1,430 & 1,030 & 491 & 3,670 \\
\hline Annual public spending (billion pesos) & 718.994 & 263.482 & 392.302 & $1,243.709$ \\
\hline Monthly household income (pesos) & 742,226 & 276,722 & 368,955 & $1,270,963$ \\
\hline Housing Price Index (2006=100) & 119 & 25 & 96 & 177 \\
\hline Population (persons) & $2,245,777$ & 119,311 & $2,058,075$ & $2,434,661$ \\
\hline $\begin{array}{l}\text { Homeownership rate (\% of the population }>18 \\
\text { years of age) }\end{array}$ & 39.8 & 3.9 & 33 & 48 \\
\hline Population density (persons per km ${ }^{2}$ ) & 3,982 & 212 & 3,649 & 4,317 \\
\hline Population growth (percent) & 1.10 & 0.10 & 1.10 & 1.20 \\
\hline
\end{tabular}

Source: National Administrative Department of Statistics, Colombia

The above data were entered into the Stata 14 program and organized by month and city. This created the panel data set for fixed-effect estimation.

\section{RESULTS AND DISCUSSION}

\subsection{Characterization of Housing Ownership in Colombia}

The information available for the main cities shows a continuous fall in the homeownership rate of urban households since 2004. In 2019, in the capital Bogotá, there were 2.3 million homes with a homeownership level of $38 \%$ compared to $48 \%$ in 2004 . In the city of Cali at the beginning of 2004 , homeownership rate was $54 \%$. However, in 2019 , of the 598,000 registered homes, $39 \%$ of people declared homeownership. Meanwhile, for the 789,000 homes in Medellin, the homeownership rate was 34\% in 2019, significantly lower than the 48\% observed in 2004 .

From the data provided by household surveys, Figures 2 and 3 were developed. Figure 2 shows the rate of homeownership by age while Figure 3 shows the rate of homeownership by income level. It appears that households that own their homes have, on average, elderly and high-income heads of household (Figures 2 and 3). This pattern is repeated in the three cities analyzed. In the $21-40$ age group $10 \%$ rents, compared to $21 \%$ in the $40-59$ age group and almost $16 \%$ in the $60+$ age group (Figure 2). There is no significant difference between genders. In terms of income, the lower and middle classes rent more. 


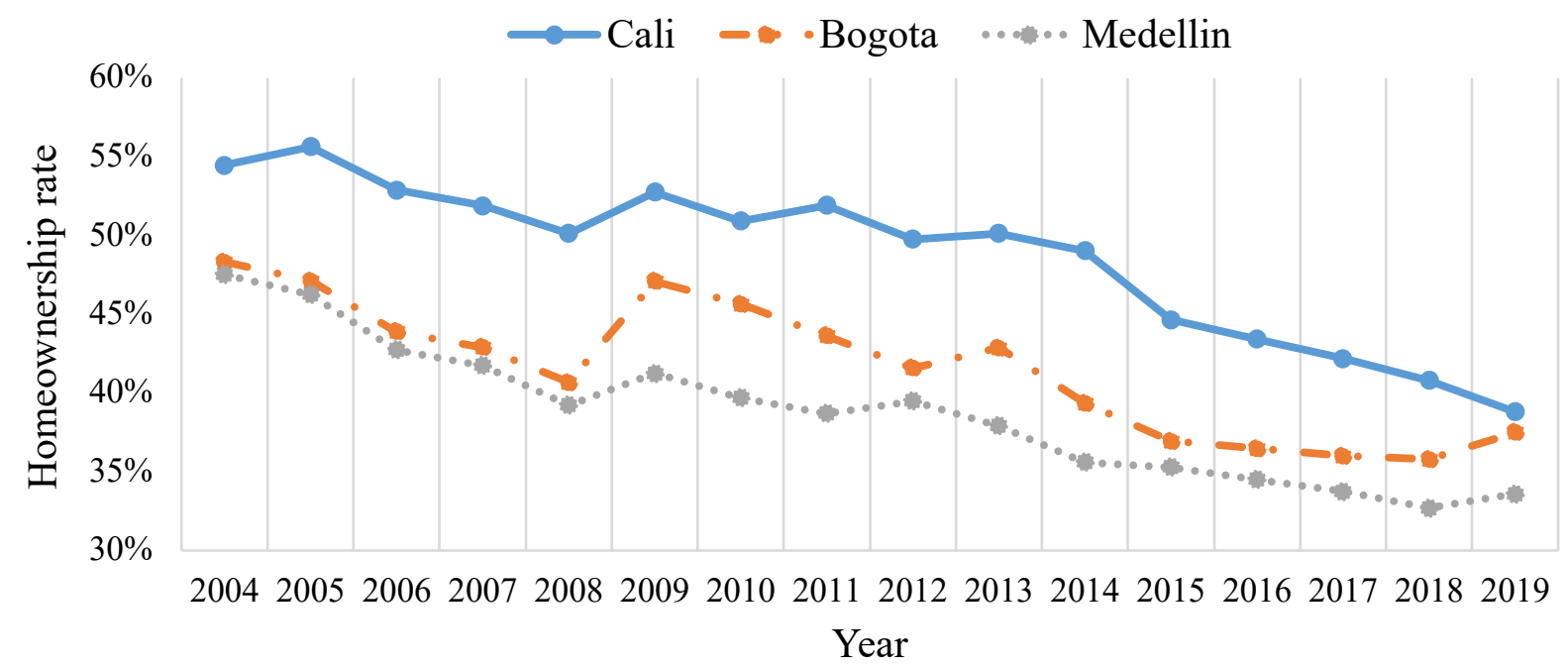

Figure 1: Distribution of Homeownership Rate by City From 2004 to 2019 (Household survey report 2004 to 2019 by National Administrative Department of Statistics)
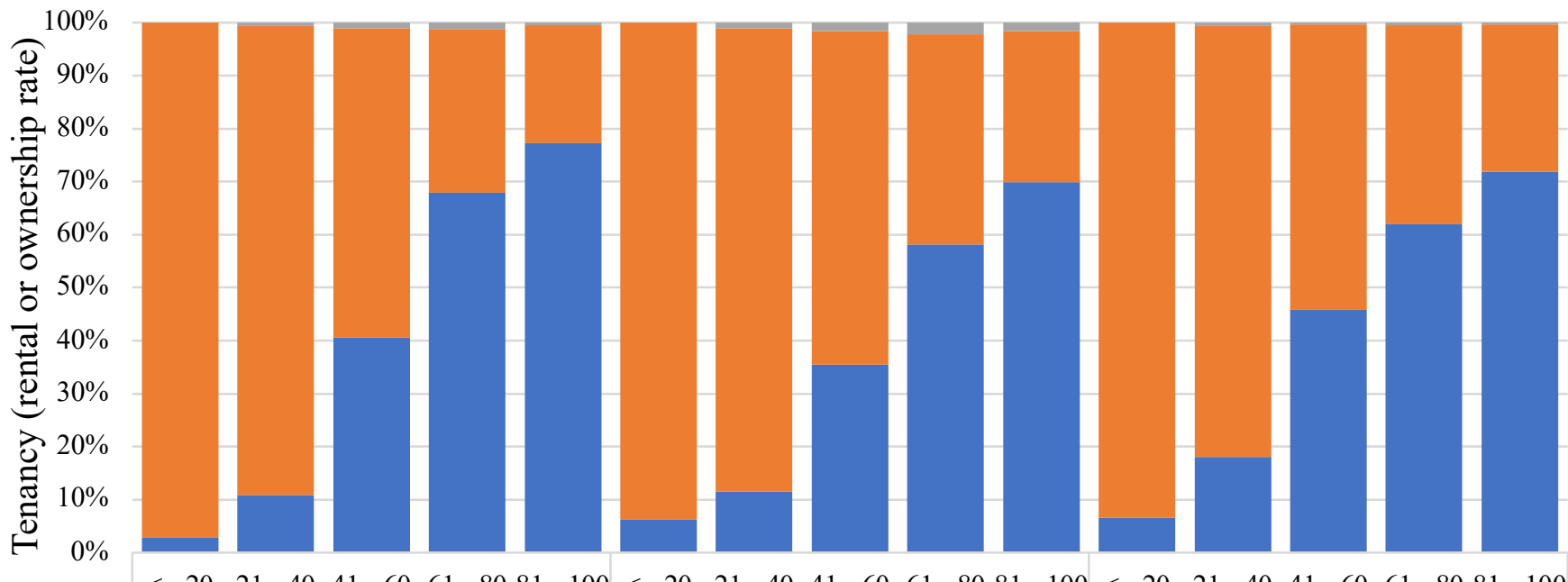

Bogota

Cali

Medellin

City and Age

own Rent

Figure 2: Distribution of Tenancy by Age in the Study Cities of Colombia (Household Survey by National Administrative Department of Statistics, 2018) 


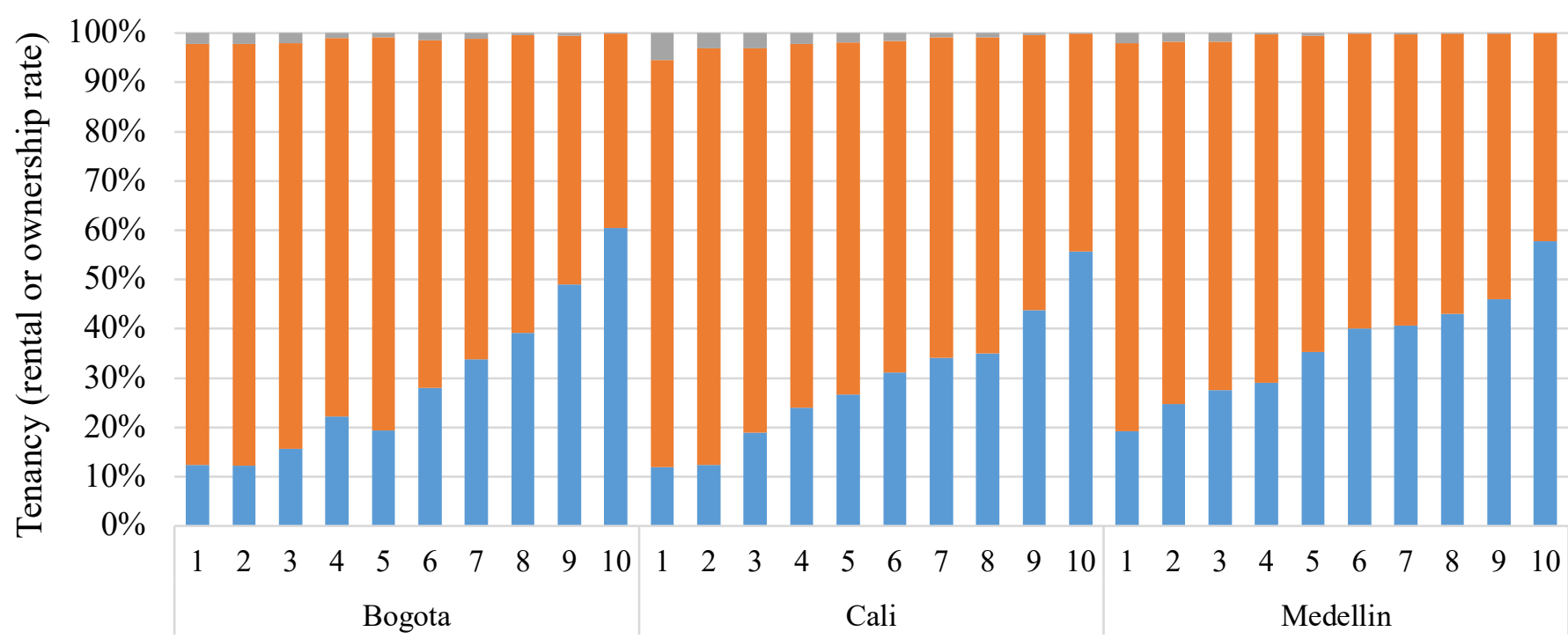

City and Income decil

- Own $\quad$ Rent

Figure 3: Distribution of Tenancy by City and Income Decile in the Study Cities of Colombia (Household Survey by National Administrative Department of Statistics, 2018)

\subsection{Model Results}

Table 2 shows the results of the estimates of the proposed model with the coefficients of each of the (independent) control variables that were significant. Table 2 also shows the indicators related to model fit. In terms of the overall fit, the model is acceptable considering that all the variables introduced presented levels of statistical significance of 5\% and according to the $\mathrm{R}$ square in the Table 2, the model manages to explain $49.7 \%$ total and $44.7 \%$ intra groups. These $\mathrm{R}$-square values are when compared to other related works in the literature are $42 \%$ for Rodriguez et al. (2018) and $74 \%$ for Peña et al. (2004). These papers find that these indicator levels are the result of the lack of explanatory variables within the proposed model. This limitation arises from the lack of sources of information that could complement the analysis of the demand for new housing, especially in developing nations.

For the interpretation of the results, the marginal effect on the continuous variables is equivalent to the percentage in which the probability increases given a change of $1 \%$ in the independent variable of analysis. Based on this interpretation, each one of the hypotheses indicated in the methodological design is reviewed.

When the hypothesis on $\mathrm{B}_{6}$ (the coefficient for percentage of people who own their homes $(\mathrm{H})$ ) is tested, it is seen in Table 2 that the coefficient (1.31) is positive, non-zero and significant according to its $P$ value $(0.00002)$. This effect is in line with the theory analyzed and its causes would lie in the fact that greater tenancy has effects on the immobilization of resources and the inelasticity of supply. 
Inferences about covariates can be interpreted thanks to coefficients. Their interpretation is percentage-based. For example, it is observed that the lag in population growth is the variable that most influences the price behavior of new housing in Colombia. A $1 \%$ increase in the population of the main cities increases its price by $53 \%$. This fact is supported by the literature related to the factors that determine the price in other countries. For example, the models by Jeanty et al. (2010) and Choi and Jung (2017) show that a stable population growth policy can moderate the growth of housing prices and economic cycles.

Table 3: Effect and Statistical Significance of Variables on the Price of New Housing in Colombia

\begin{tabular}{|c|c|c|c|c|}
\hline Variable & Coefficient & $\begin{array}{c}\text { Standard } \\
\text { Dev. }\end{array}$ & Statistical T & P value \\
\hline Constant & 3.29 & 1.320 & 2.496 & 0.018 \\
\hline Log (Mortgages) & 0.11 & 0.043 & 2.700 & 0.0114 \\
\hline Log (Ownership) & 1.311 & 0.268 & 4.870 & 0.00002 \\
\hline Log (Population Growth) & 53.089 & 19.510 & 2.720 & 0.0109 \\
\hline Log (Area of housing construction) & 0.073 & 0.015 & 4.780 & 0.000009 \\
\hline Log (Population density) & 0.002 & 0.050 & 1.200 & 0.254 \\
\hline Log (Income per capita) & 0.0373 & 0.050 & 0.740 & 0.4658 \\
\hline Log (Population) & 0.1424 & 0.421 & 0.339 & 0.7377 \\
\hline Log (Public spending) & 0.0167 & 0.016 & 1.046 & 0.3053 \\
\hline Average of dep. $=0.051683$ & & \multicolumn{3}{|c|}{ Sum of squares $=0.0309$} \\
\hline R-square $=0.49668$ & & \multicolumn{3}{|c|}{ R-square 'intra' $=0.4468$} \\
\hline Log-likelihood $=75.98$ & & \multicolumn{3}{|c|}{ Schwarz criterion $=-126.89$} \\
\hline rho $=-0.0927$ & & \multicolumn{3}{|c|}{ Akaike's criterion $=-137.97$} \\
\hline \multicolumn{2}{|l|}{ Durbin-Watson $=2.103$} & \multicolumn{3}{|c|}{ Hannan-Quinn criterion $=-134.11$} \\
\hline Average of dep. $=0.051683$ & & & & \\
\hline
\end{tabular}

Source: Author's calculations

On the mortgages side, the coefficient in the Table 2 shows that a $1 \%$ increase in the amount borrowed in mortgages, housing price increases on average by $0.09 \%$. The positive influence of mortgages on housing prices has been documented several times in the literature both theoretically (see Lambertini et al., 2013; Anundsen \& Jansen, 2013) and empirically (see Tsatsaronis \& Zhu, 2004; Botello, 2014). Its transmission channel is the market's ability to leverage the acquisition of new real estate, however, this dynamic has also been identified as a source of distortions and creation of price bubbles. 


\section{CONCLUSIONS}

Among the results is that young Colombians with low and medium incomes tend to prefer rental housing. The estimated model shows that ownership rate has a positive effect on the price of new housing, supporting the hypothesis driven by the research. However, population growth of the study cities appears to be the most important factor explaining the housing price variation. The indicators of the quantitative and qualitative housing deficits in Colombia confirm that a much higher rate of generation of housing supply is required, whether it is public or private sector housing. The results on stability and tenancy provide evidence that a more elastic housing supply could reduce, but not eliminate, the risk of housing price volatility. This would curb the economic incentives for households to spend more money on the housing market.

It is desirable to have policies to make the real estate more flexible, to regulate and facilitate the processing of construction licenses. Similarly, in line with the reasoning of Stephens (2011), a much higher rate of addition to the supply is required even to maintain current levels of housing affordability. In addition, cities require a regulatory framework that serves to stabilize housing price volatility. According to Cibils et al. (2014), leasing, including public housing, may become a better option than informal housing when household incomes are low. Creating special zones for the development of particular economic activities gives the possibility of a better urban organization. Groups such as singles, students, immigrants, and other temporary residents can take advantage of these benefits to improve their economic situation.

The experiences of various countries can guide Colombia to increase the supply and flexibility of the real estate market. Great Britain has been one of those countries that was able to increase its available supply of public housing thanks to its new policies of densification of previously restricted areas. In its private version, UK rents operate mainly on the small owner model, and are not subject to any rent control. Empirical evidence suggests that further regulation of rents and security would probably be counterproductive, as it would tend to cause property owners to withdraw from the sector or discourage them from renting property to households likely to stay there for a long time.

The limitations of this research are related to the group of variables not included in the panel data analysis that could be determinants of housing prices in Colombia, for instance, those related to the supply of housing, for example, should include household construction data by income level. Likewise, the information on cities is limited to 15 years due to the absence of data. This also affects the number of cities analyzed. Future studies in this area of research could focus on what would be the effects on household income, consumption, investment, or financial obligations of renting or owning a home.

\section{REFERENCES}

Acuña G. (2018). Apoyo en la construcción del estado del arte de planes, programas y proyectos de viviendas priorizados en los planes nacionales de desarrollo del periodo comprendido entre el 2002-2018 en Colombia. [Bachelor Thesis, Universidad Francisco Jose de Caldas]. Repositorio Institucional Universidad Distrital - RIUD. Retrieved from 
https://repository.udistrital.edu.co/bitstream/handle/11349/14082/Acu\%C3\%B1aG\%C3\% B3mezCristi\%C3\%A1n2018.pdf;sequence $=1$

Adler, D., \& Ansell, B. (2020). Housing and populism. West European Politics, 43(2), 344-365. https://doi.org/10.1080/01402382.2019.1615322

Ahearne, A. G., Ammer, J., Doyle, B. M., Kole, L. S., \& Martin, R. F. (2005). House prices and monetary policy: A cross-country study. International finance discussion papers, 841 . https://doi.org/10.2139/ssrn.816946

Anundsen, A. K., \& Jansen, E. S. (2013). Self-reinforcing effects between housing prices and credit. Journal of Housing Economics, 22(3), 192-212. https://doi.org/10.1016/j.jhe.2013.07.001

Badev, A., Beck, T., Vado, L., \& Walley, S. (2014). Housing finance across countries: new data and analysis. The World Bank. https://doi.org/10.2139/ssrn.2336126

Banks, J., Blundell, R., \& Oldfield, Z. (2004). House price volatility and housing ownership over the lifecycle. Institute for Fiscal Studies and University College, London. doi: $10.1787 / 285240733821$

Benjamin, J., Chinloy, P., \& Jud, D. (2004). Why do households concentrate their wealth in housing? Journal of Real Estate Research, 26(4), 329-344. https://doi.org/10.4337/9781785360961.00009

Betancur-Corredor, B., Loaiza-Usuga, J. C., Denich, M., \& Borgemeister, C. (2018). Gold mining as a potential driver of development in Colombia: Challenges and opportunities. Journal of cleaner production, 199, 538-553. https://doi.org/10.1016/j.jclepro.2018.07.142

Blanco, A., \& Volpe, F. (2015). Alquiler en números: la tenencia de vivienda en América Latina y el Caribe. Washington: Banco Interamericano de Desarrollo-bid. Recuperado de https://publications. iadb. org/handle/11319/6888.

Botello, H. (2014). Ciclo de crédito en el área metropolitana de Bucaramanga 20072012. Económicas CUC, 35(2), 25-38.

Bourassa, S. C., \& Hoesli, M. (2010). Why do the Swiss rent? The Journal of Real Estate Finance and Economics, 40(3), 286-309. https://doi.org/10.2139/ssrn.964637

Burdisso, T. (1997). Estimación de una función de costos para los bancos privados argentinos utilizando datos en panel. Banco Central de la República Argentina, Area de Economía y Finanzas.

Catte, P., Girouard, N., Price, R., \& André, C. (2004). OECD Economics Department Working Papers. doi: $10.1787 / 534328100627$

Chan, K. W. (2019). Social construction of gender inequality in the housing system: Housing experience of women in Hong Kong. Routledge.

Choi, C., \& Jung, H. (2017). Does an economically active population matter in housing prices? Applied Economics Letters, 24(15), 1061-1064. https://doi.org/10.1080/13504851.2016.1251547

Cibils, V. F., Blanco, A. B., Miranda, A. M., Gilbert, A., Webb, S., Reese, E., . \& Mora, P. (2014). Rental Housing Wanted: Options for Expanding Housing Policy. Inter-American Development Bank.

Clayton, J. (1996). Rational expectations, market fundamentals and housing price volatility. Real Estate Economics, 24(4), 441-470. https://doi.org/10.1111/1540-6229.00699

Escallón, C. (2011). La vivienda de interés social en Colombia, principios y retos. Revista de Ingeniería, (35), 55-60. https://doi.org/10.16924/revinge.35.10 
Favara, G., \& Imbs, J. (2010). Credit Supply and the Price of Housing. London: Centre for Economic Policy Research.

Fischel, W. A. (2009). The homevoter hypothesis. Harvard University Press. https://doi.org/10.1111/j.1468-2508.2005.00331_12.x

Furman, J. (2015). Barriers to shared growth: The case of land use regulation and economic rents. Remarks delivered at the Urban Institute, Washington, DC, November 20.

Glaeser, E. L., \& Gyourko, J. (2003). The impact of building restrictions on housing affordability. Economic Policy Review, 9(2).

Glaeser, E. L., Gyourko, J., \& Saks, R. E. (2005). Why have housing prices gone up? American Economic Review, 95(2), 329-333. https://doi.org/10.1257/000282805774669961

Han, L. (2010). The effects of price risk on housing demand: empirical evidence from US markets. The Review of Financial Studies, 23(11), 3889-3928. https://doi.org/10.1093/rfs/hhq088

Hashim, Z. A. (2010). House price and affordability in housing in Malaysia. Akademika, 78(1). https://doi.org/10.21837/pmjournal.v17.i9.604

He, C., Wright, R., \& Zhu, Y. (2015). Housing and liquidity. Review of Economic Dynamics, 18(3), 435-455. https://doi.org/10.1016/j.red.2014.10.005

Herkenhoff, K. F., Ohanian, L. E., \& Prescott, E. C. (2018). Tarnishing the golden and empire states: Land-use restrictions and the US economic slowdown. Journal of Monetary Economics, 93, 89-109. https://doi.org/10.3386/w23790

Huang, H., \& Tang, Y. (2012). Residential land use regulation and the US housing price cycle between 2000 and 2009. Journal of Urban Economics, 71(1), 93-99. https://doi.org/10.1016/j.jue.2011.08.001

Igan, D., \& Kang, H. (2011). Do loan-to-value and debt-to-income limits work? Evidence from Korea. IMF Working Papers, 1-34. https://doi.org/10.2139/ssrn.1915127

Illing, G., Ono, Y., \& Schlegl, M. (2018). Credit booms, debt overhang and secular stagnation. European Economic Review, 108, 78-104. https://doi.org/10.1016/j.euroecorev.2018.06.004

Jeanty, P. W., Partridge, M., \& Irwin, E. (2010). Estimation of a spatial simultaneous equation model of population migration and housing price dynamics. Regional Science and Urban Economics, 40(5), 343-352. https://doi.org/10.1016/j.regsciurbeco.2010.01.002

Klyuev, V., \& Mills, P. (2007). Is housing wealth an “ATM”? The relationship between household wealth, home equity withdrawal, and saving rates. IMF Staff Papers, 54(3), 539-561. https://doi.org/10.5089/9781451864229.001

Kok, N., Monkkonen, P., \& Quigley, J. M. (2014). Land use regulations and the value of land and housing: An intra-metropolitan analysis. Journal of Urban Economics, 81, 136-148. https://doi.org/10.1016/j.jue.2014.03.004

Kuethe, T. H., \& Pede, V. O. (2011). Regional housing price cycles: a spatio-temporal analysis using US state-level data. Regional studies, 45(5), 563-574. https://doi.org/10.1080/00343400903497897

Lai, F., Chan, S. N., Shum, W. Y., \& Zhou, N. (2017). Household Debt and Housing Price: An Empirical Study Across 36 Countries. International Journal of Business and Management, 12(11), 227-241. https://doi.org/10.5539/ijbm.v12n11p227

Lai, N., \& Wang, K. (1999). Land-supply restrictions, developer strategies and housing policies: the case in Hong Kong. International Real Estate Review, 2(1), 143-159. https://doi.org/10.5790/hongkong/9789888208654.003.0004 
Lambertini, L., Mendicino, C., \& Punzi, M. T. (2013). Leaning against boom-bust cycles in credit and housing prices. Journal of Economic Dynamics and Control, 37(8), 1500-1522. https://doi.org/10.2139/ssrn.1789573

Lens, M. C., \& Monkkonen, P. (2016). Do strict land use regulations make metropolitan areas more segregated by income? Journal of the American Planning Association, 82(1), 6-21. https://doi.org/10.1080/01944363.2015.1111163

Ortalo-Magne, F., \& Rady, S. (1999). Boom in, bust out: young households and the housing price cycle. European Economic Review, 43(4-6), 755-766. https://doi.org/10.2139/ssrn.137961

Oswald, A. J. (1996) A conjecture on the explanation for high unemployment in the industrialized nations: part I. Warwick Economics Research Paper, No. 475, University of Warwick.

Paciorek, A. (2013). Supply constraints and housing market dynamics. Journal of Urban Economics, 77, 11-26. https://doi.org/10.15517/nat.v10i2.26110

Peña, M., Ruiz, V. y García, J. D. (2004). Análisis de los factores determinantes del precio del activo vivienda. Análisis Financiero, 64-74.

Rodriguez, J. C., Delgado, P. F., \& Botello, T. (2018). Determinantes del precio de la vivienda en Bucaramanga. Equidad y Desarrollo, 1(30), 39-59. ¿ doi:10.19052/ed.3649

Saks, R. E. (2004). Housing supply restrictions across the United States. Wharton Real Estate Review, 8(2), 43-51. https://doi.org/10.1093/acrefore/9780199329175.013.596

Shiller, R. (2007). Understanding Recent Trends in House Prices and Home Ownership. NBER papers. 304. doi:10.3386/w13553.

Sierra, A. P. C., \& Tarazona, A. H. (2011). Vivienda y pobreza: una relación compleja. Marco conceptual y caracterización de Bogotá. Cuadernos de vivienda y urbanismo, 4(8). https://doi.org/10.26422/icf.2018.cong05.alv

Stephens, M. (2011). Tackling Housing Market Volatility in the UK. Part I: Long- and Short-term Volatility. International Journal of Housing Policy, 12(3), 367-380. doi:10.1080/14616718.2012.709674

Tsatsaronis, K., \& Zhu, H. (2004). What drives housing price dynamics: cross-country evidence. BIS Quarterly Review. https://doi.org/10.1016/j.econmod.2012.03.029

$\mathrm{Wu}, \mathrm{Y} ., \& \mathrm{Li}, \mathrm{Y}$. (2018). Impact of government intervention in the housing market: evidence from the housing purchase restriction policy in China. Applied Economics, 50(6), 691-705. doi:10.1080/00036846.2017.1340569 